\title{
Seasonal Variations of Some Physico-Chemical Properties of River Ethiope Water in Abraka, Nigeria
}

\author{
${ }^{1}$ AGBAIRE, P.O.; OBI, C.G. \\ ${ }^{I}$ Department of Chemistry, Delta State University P.M.B. 1, Abraka Delta State, Nigeria. \\ Email address: patagbaire.gmail.@.com.
}

\begin{abstract}
The influence of seasonal changes on the properties of water from Ethiope River at Abraka was investigated. Composite samples from six different sampling points were collected and assessed for both dry and wet seasons. The sampling points represent the villages within Abraka clan along the river. The seasonal variations are as follows. Wet season has mean $\mathrm{pH}$ as 6.82 , temperature $27.73^{\circ} \mathrm{C}$ conductivity $81.7 \mu \mathrm{s} / \mathrm{cm}$, TDS $0.26 \mathrm{mg} / 1$ TSS 16.21 , DO $16.80 \mathrm{mg} / 1$, BOD $4.50 \mathrm{mg} / \mathrm{l}$. The results for the dry season is as follows; mean $\mathrm{pH} 6.82$, temperature $29.150 \mathrm{C}$, conductivity $87.2 \mu \mathrm{s} / \mathrm{cm}$, TDS $0.34 \mathrm{mg} / \mathrm{l}$, TSS $15.21 \mathrm{mg} / 1$, DO $17.45 \mathrm{mg} / 1$, BOD $4.38 \mathrm{mg} / \mathrm{l}$. The result of heavy metal content showed that they were within the permissible levels. This water can therefore be said to be portable in all seasons. @ JASEM
\end{abstract}

Water bodies are constantly used as receptacles for untreated waste water or poorly treated effluents accrued from industrial activities. This may render the water bodies unsuitable for both primary and/or secondary usuage. One of the most critical crisis in developing countries is the lack of adequate portable water. The usual source of drinking water is from streams, rivers, wells and boreholes which are usually not treated. In the Niger Delta region of Nigeria, the problem is getting portable water because of environmental pollution and degradation (Efe 2002). Several studies in Nigeria had identified anthropogenic activities as easy source of water pollution (Akintola and Nyamah, 1978; Ayoade, 1988 and 1994, Ayoade and Oyebande, 1983, Kaizer et al 2001; Obasi and Balogun 2001; Ovrawah and Hymore 2001). Though water is important to life, it is one of the most poorly managed resources in the world (Fakayode 2005). The geology of the Western Niger Delta region is of the sedimentary type with a lithology of top layer of silty clay, and sand, followed by a thick sand layer (Okoye et al 1987). This is coupled with the tropical equatorial climate with annual rainfall of $3,000 \mathrm{~mm}$ which allows rapid drainage of the abundant rainfall that leaches pollutants into the subsurface water systems (Efe et at 2005). In this country, environmental monitoring agencies seem and not to be too effective, so any abnormal change in water quality is not promptly identified and dealt with except when there is epidemic. This work is therefore aimed at studying the water quality as well as it's seasonal variation.

\section{MATERIALS AND METHODS}

Six sampling points at communities along the river in Abraka clan were chosen. The selection was based on the point where the communities most frequently collected water for drinking and other domestic work. The communities are Umeghe, Otorho, Urhuoka, Ekrejeta, Erho and Oria. Water sample was collected twice in the year i.e December which represent the Dry season and July the wet season. At each sampling location, composite surface water was collected at the middle of the river and stored in clean polyethylene bottles that have been pre-washed with $\mathrm{HNO}_{3}$ and thoroughly rinsed with deionised water. Samples for heavy metals analyses were acidified in-situ with $5 \mathrm{ml} \mathrm{HNO}_{3}$. Nonconservable parameters such as $\mathrm{pH}$, temperature and electrical conductivity were determined at the time of sampling in the field. The $\mathrm{pH}$ of water sample was measured with a $\mathrm{pH}$ meter previously calibrated with buffer solutions. Conductivity was measured with a conductivity meter calibrated with potassium chloride solution. Temperature was measured with a thermometer. Alkalinity was determined by titrating a known volume of water sample with $0.02 \mathrm{MHCl}$. Dissolved oxygen (DO) was determined by Winkler's titration. Total dissolved solid (TDS) was determined gravimetrically by evaporating a known volume of water to dryness in a pre-weighed crucible on a steam bath. Total suspended solids (TSS) was determined by filtering a known volume of sample through a thoroughly dried filter paper and the residue weighed. Total Hardness was determined by titrating with EDTA using Eriochrome black $\mathrm{T}$ as indicator. Biological Oxygen Demand (BOD) was done using the relationship $\mathrm{BOD}=\mathrm{DO}_{-} \mathrm{DO}_{5}$ (APHA 1995). Heavy metal was determined by digesting a known volume of water sample with analytical grade $\mathrm{HNO}_{3}$. This was filtered into a $20 \mathrm{ml}$ standard flask, made up to mark with distilled-deiomised water and stored in a nitric acid pre-washed polyethylene bottle in the refrigerator prior to analysis. Metal analysis was carried out using GBC sens Atomic Absorption Spectrophotomer model 01-0960-00. Each sample was analysed in duplicate and the mean result reported. General laboratory quality assurance measures were always maintained. 
RESULTS AND DISCUSSION

\begin{tabular}{|c|c|c|c|c|c|c|c|c|}
\hline Parameters & Umeghe & Otorho & Urhuoka & Ekrejeta & Erho & Oria & Mean & $\begin{array}{l}\text { WHO } \\
\text { Limits }\end{array}$ \\
\hline Temperature ${ }^{\circ} \mathrm{C}$ & 28.0 & 27.0 & 26.9 & 28.0 & 28.0 & 28.50 & 27.73 & $30-35$ \\
\hline $\mathrm{pH}$ & 7.20 & 6.70 & 7.30 & 7.40 & 6.40 & 6.95 & 6.99 & $6.50-8.50$ \\
\hline conductivity $\mu \mathrm{s} / \mathrm{cm}$ & 84 & 74 & 86 & 92 & 73 & 81 & 81.7 & N/A \\
\hline TDS mg/L & 0.99 & 0.06 & 0.09 & 0.10 & 0.74 & 0.15 & 0.25 & $>1$ \\
\hline $\mathrm{TSS} \mathrm{mg} / \mathrm{L}$ & 18.30 & 10.33 & 13.10 & 22.31 & 16.08 & 17.12 & 16.21 & 30.0 \\
\hline Total Hardness mg/L & 1.80 & 2.40 & 2.40 & 3.60 & 2.80 & 1.60 & 2.43 & $300-500$ \\
\hline $\mathrm{DO} \mathrm{mg} / \mathrm{L}$ & 11.60 & 16.70 & 15.60 & 22.00 & 19.40 & 15.50 & 16.80 & 73.00 \\
\hline BOD mg/L & 2.9 & 5.0 & 3.80 & 4.2 & 5.8 & 5.5 & 4.5 & $20-40$ \\
\hline Alkalinity $\mathrm{mgCaCO}_{3} / \mathrm{L}$ & 1.30 & 1.60 & 1.40 & 1.70 & 1.50 & 1.20 & 1.45 & $200-600$ \\
\hline Fe ppm & $<0.001$ & $<0.001$ & $<0.001$ & $<0.001$ & $<0.001$ & $<0.001$ & $<0.00$ & 0.03 \\
\hline $\mathrm{Pb}$ ppm & 0.027 & $<0.001$ & $<0.001$ & $<0.001$ & $<0.001$ & $<0.001$ & 0.005 & 0.01 \\
\hline Ni ppm & $<0.001$ & $<0.001$ & $<0.001$ & $<0.001$ & $<0.001$ & $<0.001$ & $<0.001$ & N/A \\
\hline
\end{tabular}

Table II: Dry Season

\begin{tabular}{|c|c|c|c|c|c|c|c|c|}
\hline Parameters & Umeghe & Otorho & Urhuoka & Ekrejeta & Erho & Oria & Mean & WHO Limits \\
\hline Temperature ${ }^{\circ} \mathrm{C}$ & 29.0 & 29.0 & 29.40 & 29.00 & 29.50 & 29.00 & 29.15 & $30-35$ \\
\hline $\mathrm{pH}$ & 6.90 & 6.60 & 7.00 & 7.10 & 6.50 & 6.80 & 6.82 & $6.50-8.50$ \\
\hline conductivity $\mu \mathrm{s} / \mathrm{cm}$ & 92 & 89 & 82 & 98 & 84 & 78 & 87.2 & N/A \\
\hline TDS mg/L & 0.98 & 0.04 & 0.07 & 0.08 & 0.72 & 0.13 & 0.34 & $>1$ \\
\hline $\mathrm{TSS} \mathrm{mg} / \mathrm{L}$ & 17.30 & 9.33 & 12.10 & 21.31 & 15.08 & 16.12 & 15.21 & 30.0 \\
\hline Total Hardness mg/L & 2.4 & 1.00 & 2.80 & 4.10 & 1.00 & 3.20 & 2.42 & $300-500$ \\
\hline $\mathrm{DO} \mathrm{mg} / \mathrm{L}$ & 13.40 & 17.00 & 14.80 & 24.00 & 18.30 & 17.20 & 17.45 & 73.00 \\
\hline BOD mg/L & 3.80 & 5.20 & 1.40 & 7.70 & 4.0 & 4.20 & 4.38 & $20-40$ \\
\hline Alkalinity $\mathrm{mgCaCO}_{3} / \mathrm{L}$ & 1.50 & 1.80 & 1.60 & 1.80 & 1.70 & 1.50 & 1.65 & $200-600$ \\
\hline Fe ppm & 0.022 & 0.036 & 0.032 & 0.028 & 0.020 & 0.016 & 0.026 & 0.03 \\
\hline $\mathrm{Pb}$ ppm & 0.020 & 0.016 & 0.010 & 0.017 & 0.013 & 0.011 & 0.015 & 0.01 \\
\hline Ni ppm & $<0.001$ & $<0.001$ & $<0.001$ & $<0.001$ & $<0.001$ & $<0.001$ & $<0.001$ & N/A \\
\hline
\end{tabular}

$<0.001$ below detectable limit. N/A not available

The water samples from all the points were colourless, tasteless and odourless except that from Otorho with a bit brownsh colour. According to Fakayode (2005), the $\mathrm{pH}$ of a water body is very important in determination of water quality since it affects other chemical reactions such as solubility and metal toxicity. The $\mathrm{pH}$ of the water under study in both seasons are within the WHO standard of $6.50-8.50$. The average $\mathrm{pH}$ for dry is 6.82 while that of the wet season is 6.99. Thus near the neutral point. This water could therefore be regarded as neutral and unpolluted (Fakayode 2005). The total dissolved solids with a mean of $0.34 \mathrm{mg} / \mathrm{l}$ during the dry season and $0.26 \mathrm{mg} / \mathrm{l}$ in the wet season is also below the WHO standard indicative of portability. The total dissolved solids gives an indication of the degree of dissolved substances. Dissolved oxygen (DO) is very crucial for survival of aquatic organisms and it is also used to evaluate the degree of freshness of a river (Fakayode 2005). The DO level of this part of the river is relatively high (mean $16.8 \mathrm{mg} / \mathrm{L}$ wet season, $17.45 \mathrm{mg} / \mathrm{L}$ dry season) as compared with other results (Phiri et al 2005, Fakayode 2005, Emoyan et al 2000). The values are also within the WHO permissible limits. The BOD's were within the WHO standards. All metal analysed were within the Who permissible limit for portable water.

In conclusion therefore the river water which is one of the main sources of drinking water in this area is portable and not polluted.

\section{REFERENCES}

Adebola, K.D. (2001): Groundwater Quality in Ilorin Township: An Experimental Review. African Journal of Environmental Studies 2(2) 4-6.

Akintola, F.O. and Nyamah N.C. (1978) Land-use and surface water pollution in Ibadan. In Efe, S.I. et al: seasonal variations of PhysicoChemical Characteristics In Water Resources. Quality in Western Niger Delta Region, Nigeria. J. Appl. Sci ENviorn. Mgt 2005 9(1) 191-195.

Akporido, S.O. Emuobonuvie J. and Akporido C.E. (2000). A study of the Quality Characteristics of Surface and Underground Water in Sapele and Ogharefe Oil Producing Areas in Delta State. Nigerian Journal of Science and Environment 2:17-22.

APHA (1995); Standard Methods for the Examination of Water and Wastewater. $19^{\text {th }}$ edu. American Public Health Association.

Ayoade J.O. and oyebande, B.C. (1983). Water Resources in Efe, S.I. et al. Seasonal Variations of Physico-Chemical Characteristics in Water Resources Quality in Western Niger Delta Region, Nigeria J. Appl. Sci. Environ. Mgt 2005 9(1) 191-195. 
Ayoade, J.O. (1994); Human Impact on the ENviornment. In Filani et al (eds) Ibadan Region, Ibadan. Rex Charles Pub.

Efe, S.I.; Ogban, F.E; Horsefall, M. Jnr; and Akporhonor E.E. (2005); Seasonal Variations of Physico-Chemical Characteristics in Water Resources Quality in Western Niger Delta Region, Nigeria. J. Appl. Sci. Environ. Mgt 9(1) 191-195.

Efe, S.T. (2000): An Appraisal of the Quality of Rain and Groundwater Resources in Nigerian Cities. The case of Warri Metropolis. A. Ph.D seminar paper presented to the Department of Geography and Regional Planning, Delta State University, Abraka.

Fakayode, S.O. (2005): Impact Assessment of Industrial Effluent on Water Quality of the Receiving ALaro River in Ibadan, Nigeria. Ajeam-Ragee Volume 10, 1-13.

Kaizer, A.N.; Adaikpoh E.O. Osakwe, S.A. and Obanogun-Odiete, E. (2001); Heavy Metal Pollution of Surface Water within Coal Mining Sites around Enugu, South-Eastern Nigeria. Agid 1-5.
Obasi R.A. and Balogun O. (2001); Water Quality and Environmental Impact Assessment of Water Resources in Nigeria. African Journal of Environment Studies 2(2) 228-231.

Okoye, N.V., Schoutan Jr, and O'sullivan A.J. (1987); Monitoring and Evaluation of Oil Related Pollution in NNPC Operation. In Proceeding of the 1987 Seminar on the Petroleum Industry and Nigeria Environment held at Imo Concorde Hotel, Owerri.

Ovrawah, L. and Hymore, F.K. (2001). Quality of Water from Hand-Dug Wells in Warri Environs of Niger Delta Region. African Journal of Environmental Studies 2(2) 169173.

Phiri O; Mumba, P; Moyo, B.H.Z. and Kadewa, W. (2005): Assessment of the Impact of Industrial Effluents on Water Quality of Receiving Rivers in Urban Areas of Malawi. Int. J. Environ Sci. Tech. 2(3) 237-244.

WHO (1995): World Health Organization. Guideline for Drinking Water Quality. Geneva. 